\title{
Scrotal cancer in the north-west of England, 1962-68
}

\author{
W. R. LEE, M. R. ALDERSON', and JEAN E. DOWNES \\ Department of Occupational Health and Department of Social and Preventive Medicine, \\ University of Manchester
}

\begin{abstract}
Lee, W. R., Alderson, M. R., and Downes, J. E. (1972). Brit. J. industr. Med., 29, 188-195. Scrotal cancer in the north-west of England, 1962-68. During the seven years 1962 to 1968 there were 103 cases of scrotal cancer reported to the Manchester Regional Cancer Registry. It was possible to obtain reasonably full occupational histories concerning 89 of these cases either from the men themselves or from close relatives. Fifty-one had been mule spinners, 40 of whom had worked in no other industry with a hazard of scrotal cancer, but the other 11 had. Another 19 men had never been mule spinners but had worked in occupations with a recognized hazard of this condition. Of the remainder, 14 had worked in occupations with a possible risk, although perhaps not generally recognized as such, and in five no clear cause was apparent. Because of the small numbers, it was possible to compare the observed and expected incidences only in broad occupational groups and these showed a statistically significant excess $(\mathbf{P}<0.001)$ only in textile workers and unskilled workers. However, our findings, taken with those of earlier workers, suggest that further attention might be given to four other groups, namely, automatic lathe operators, road workers, dye workers, and chain makers.

Cancer of the scrotum tends to be a disease of the elderly. In $42 \%$ of men (other than mule spinners) scrotal cancer developed after the men had passed the age of retirement and therefore too late for routine medical examination at the workplace to be of any value. Fifty of the men had died, but scrotal cancer was registered as the underlying cause in only 19 and appeared on the death certificate in a further four.
\end{abstract}

Since the work of Henry (1946) and of Cruickshank and Squire (1950) from Birmingham there have been no reports on the occupational incidence of scrotal cancer in this country. This may be because the annual number of deaths attributed to this cause has been falling (Fig. 1).

Recently, there has been an increased concern over the induction of scrotal cancer by mineral oils used in industry (Stokes $v$. Guest, Keen and Nettlefold Ltd., 1968; Medical Research Council, 1968; Kipling, 1968). As a result, doctors working in industry have been interested to know what occupa-

${ }^{1}$ Now at Department of Medical Information Science, University of Southampton tions are at risk. While the present occurrence of occupational cancer probably reflects causative conditions of many years ago, we have, at present, no other way to discover those occupations in which a 1 isk is developing than to look at the present incidence of this cancer.

\section{Method}

Particulars were obtained from the Manchester Regional Cancer Registry of all patients notified as having scrotal cancer from 1 January 1962 to 31 December 1968. The Registry records were examined to check that there were adequate grounds for the diagnosis. The family practitioners were asked about the advisability of approaching the patient, if still surviving, or his relative. This 


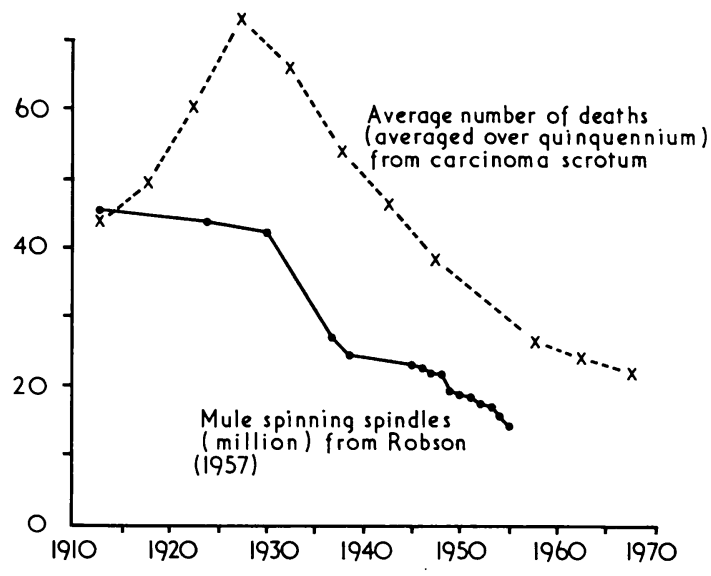

FIG. 1. Deaths from cancer of the scrotum and the number of mule spinners.

person was contacted and interviewed by J.E.D. who obtained a detailed occupational history. Three patients had moved more than 50 miles from Manchester and enquiries were made by post. In some instances, particularly when relatives were interviewed, the occupational history was incomplete and permission was obtained from the respondent for one of us (W.R.L. or J.E.D.) to contact the firm or firms where the patient had worked so that more details could be obtained.

If the patient had died, particulars of the certified cause of death were generally available from the Regional Cancer Registry records, but if the information was incomplete a copy of the death certificate was obtained from the local Registrar of Deaths.

An occupation might appear frequently because it occurs commonly in the region or because of a causal relationship between the occupational environment and the disease. To try to distinguish these more fully, we have compared the distribution of reported occupations with the distribution of occupations recorded in the 1931 and 1951 censuses (General Register Office 1934, 1956); these censuses cover the main period when the men in this study were at work. No census was carried out for 1941. Because the majority of our subjects were of retiring age by 1961 , there was no point in comparing our findings with this census report.

We have used data for the north-west region from the 1931 census report, and for the northern region No. 4 from the 1951 census report. These regions are comparable with the current Manchester Regional Hospital Board Area, in which the subjects in the study lived at the time of the diagnosis of their scrotal cancer. The 1931 census is not tabulated by age. This creates a problem because the differences between those 'observed' in our subjects and those 'expected' from the census material may be due in part to the differences in age distributions of the two populations. We have restricted the comparisons with the 1931 census to all occupied males aged 14 and over, including those out of work at the time of the census. We have not included those reported as being unoccupied or retired at the time of the census. For comparison with the 1951 census we have included men reported as unoccupied or retired.

\section{Results}

There had been 103 notifications of scrotal cancer during the period under survey and the number of cases notified in each year is shown in Table 1 . We were unable to trace six men, five others refused to be visited, and in three further cases the information gathered was inadequate for use. This paper is therefore concerned with the remaining 89 men.

In Table 2 the patients have been classified into broad occupational groups. As would be expected in this area, there were many mule spinners. Forty patients had worked in mule spinning only or in mule spinning and some other occupation, such as a warehouseman with paper, in which there is no known increased risk of scrotal cancer (group A). Eleven other men had worked both in mule spinning and in other occupations with a possible risk of scrotal cancer (group B). A third group, 19 men, had worked in occupations other than mule spinning in which there is some known risk of scrotal cancer (group C). The fourth group, 14 men, had worked

TABLE 1

Number of Patients Registered at Manchester Regional Cancer Registry With Scrotal Cancer PER YeAR 1962-68 AND Numbers Traced IN THIS SURVEY

\begin{tabular}{c|c|c}
\hline Year & No. of notifications & No. traced \\
\hline 1962 & 13 & 11 \\
1963 & 21 & 17 \\
1964 & 14 & 11 \\
1965 & 20 & 18 \\
1966 & 7 & 7 \\
1967 & 18 & 18 \\
1968 & 10 & 7 \\
\hline & 103 & 89 \\
\hline
\end{tabular}

TABLE 2

Number of Patients in Each Classification

\begin{tabular}{c|l|c}
\hline Group & \multicolumn{1}{|c}{ Classification } & No. \\
\hline A & Mule spinning ONLY (see text) & 40 \\
B & Mule spinning and other possible causes & 11 \\
C & Cause clear but NOT mule spinning & 19 \\
D & NOT recosnized but feasible cause & 14 \\
E & No clear cause & 5 \\
\hline & & 89 \\
\hline
\end{tabular}


in occupations in which, although scrotal cancer is not a generally recognized hazard, it seemed reasonable to connect their disease with their occupation (group D). Finally, there remained five men, in whom no definite cause was found for their scrotal cancer (group E).

Table 3 lists the years spent in mule spinning by the men in group A.

Table 4 lists the 11 mule spinners (group B) who had also worked in some other job where a risk of scrotal cancer could not be entirely ruled out. These have been divided into three classesexposure to mineral oils; exposure to tar products;

TABLE 3

Group A: Mule SpinNers only, Other OccupaTIONS NOT CONSIDERED HAZARDOUS (SEE TEXT)

\begin{tabular}{c|c}
\hline Years as a mule spinner & No. of respondents \\
\hline $1-9$ & 1 \\
$10-19^{2}$ & 5 \\
$20-29$ & 8 \\
$30-39$ & 8 \\
$40-49^{3}$ & 10 \\
$50-59$ & 8 \\
\hline & 40 \\
\hline
\end{tabular}

${ }^{1}$ End point EITHER leaving industry OR first sought medical advice, whichever is the earlier.

One man worked 4 years part time, followed by 8 years full time which is taken notionally as 10 years (i.e., 4 years part time $=2$ years full time).

${ }^{3}$ One man worked 42 years full time followed by 5 years part time which is taken notionally as $44 \frac{1}{2}$ years (i.e., 5 years part time $=2 \frac{1}{2}$ years full time) other exposure. All are arranged in increasing order by years spent mule spinning.

Group C, men with a recognizable occupational cause other than mule spinning, is shown in Table 5. They have been divided into the same three classes as the men in Table 4.

Table 6 lists those men (group D) who had worked in occupations in which, although scrotal cancel is not a generally recognized hazard, it seemed reasonable to connect the disease and the occupation. They have been put into three classes-textile workers, automobile workers, and others.

There were five persons in whom no clear connexion could be seen between their occupation and the scrotal cancer (group E). Their occupations were: clerk in tannery works, haulage driver, cabinet maker and timber retailer, drawer-in (textile), and milk bottle cleaner then galvanizer.

The 84 men in groups $A$ to $D$ have been grouped in Table 7 according to the period from their first known exposure to a possible carcinogen to the date when they first sought medical advice. This stage of the disease has been taken as the point of reference because it can readily be fixed by the respondent in all cases and confirmed, if necessary, from the hospital records. In all except two instances, the patients had been referred to hospital within six months of first seeing the doctor and the necessary treatment had been started. The other two cases were referred within 12 months. Attempts to use the onset of symptoms, while theoretically desirable, failed. This is because a few of the more perspicacious men had noticed small scrotal tumours or warts many years before going to the doctor. To take the reported date of the appearance of the first symptoms would have confused the initial awareness

TABLE 4

Group B: Mule Spinning and Other Causes (11 Men)

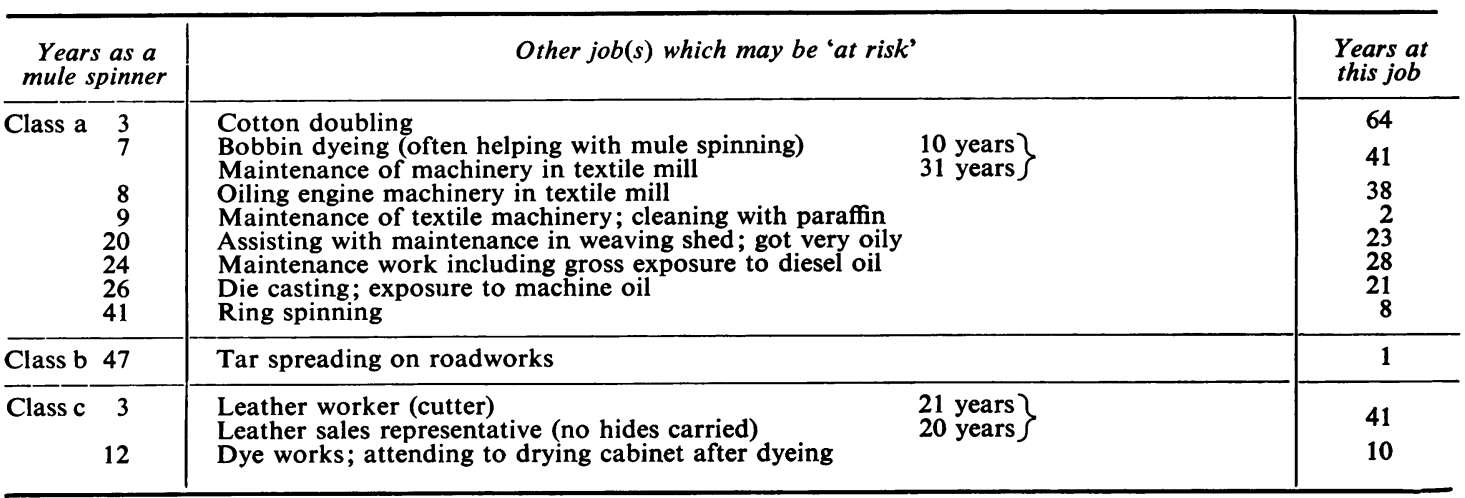

Class a Exposure to mineral acid

b Exposure to tar or its products

c Other exposure 
TABLE 5

Group C: Clear Occupational Hazard, excluding Mule Spinning (19 Men)

\begin{tabular}{|c|c|c|}
\hline \multicolumn{2}{|c|}{$\begin{array}{l}\text { Years of } \\
\text { exposure }\end{array}$} & Occupation \\
\hline Class a & $\begin{array}{l}17 \\
20 \\
28 \\
31 \\
32 \\
32\end{array}$ & $\begin{array}{l}\text { Auto machine setter } \\
\text { Capstan lathe operative } \\
\text { Capstan lathe operative } \\
\text { Auto machine operative } \\
\text { Auto setter } \\
\text { (30) Wire rope splicing } \\
\text { (2) Die casting } \\
\text { Lathe machine operative } \\
\text { Auto setter } \\
\text { (30) Gear cutting } \\
\text { (12) Centre lathe turner } \\
\text { Textile machinery operative (very oily) } \\
\text { Auto-gear cutting }\end{array}$ \\
\hline Class b & $\begin{array}{l}47 \\
55\end{array}$ & $\begin{array}{l}\text { Highways Department carrying tar and pitch } \\
\text { (9) Tarring ropes } \\
\text { (20) Maintenance of steam wagon (very oily } \\
\text { job) } \\
\text { (6) Maintenance of motor lorries } \\
\text { (10) Tar distilling } \\
\text { (4) Tar acid piant } \\
\text { (2) Benzole and solvent plant } \\
\text { (21) Works manager (in same plant regularly) } \\
\text { (21) Road mender } \\
\text { (21) Chimney sweep } \\
\text { Tar spraying } \\
\text { (23) Furnace hand } \\
\text { (32) Gas rurnace man (see text, i.e., notes of } \\
\text { patient) }\end{array}$ \\
\hline Class $\mathrm{c}$ & 48 & $\begin{array}{l}\text { (2) Boiler cleaner on railway (soot) } \\
\text { (34) Ship's engineer } \\
\text { (12) Maintenance of static engine } \\
\text { (7) Road making (see text) } \\
\text { (43) Barbed wire machine operative }\end{array}$ \\
\hline
\end{tabular}

Class a Exposure to oil

b Exposure to tar or its products

c Other exposure

of the patient to abnormality with the date of the first clinical manifestation of a carcinoma of the scrotal skin.

Table 8 shows the ages at which patients first sought medical advice and Table 9 shows the ages at death.

The certified cause of death of the 50 men who had died was coded according to the rules of the International Classification of Diseases (World Health Organisation, 1957). Scrotal cancer was the underlying cause of death in 19 subjects. Of the remainder, scrotal cancer appeared on the death certificate in $\mathbf{4}$ and was not mentioned in 27 instances (Table 10).

Tables 11 and 12 show the distribution by occupational orders of the subjects in this study. From the
TABLE 6

Group D: OCCupations NOT GENERALly RECOGNized as Hazardous but Feasible (14 Men)

\begin{tabular}{|c|c|c|}
\hline \multicolumn{2}{|c|}{$\begin{array}{c}\text { Years } \\
\text { exposed }\end{array}$} & Occupation \\
\hline Class i & $\begin{array}{l}37 \\
53 \\
54 \\
57\end{array}$ & $\begin{array}{l}\text { Oiling and greasing cotton machinery } \\
\text { Stripper and grinder } \\
\text { Bobbin carrier and oiling cotton machinery } \\
\text { Stripper and grinder }\end{array}$ \\
\hline Class ii & $\begin{array}{l}10 \\
47 \\
51\end{array}$ & $\begin{array}{l}\text { Car assembly } \\
\text { (37) Motor mechanic and driver } \\
\text { (10) Wool ring spinner } \\
\text { Automobile repairer }\end{array}$ \\
\hline Class iii & $\begin{array}{r}6 \\
10 \\
13 \\
24 \\
25 \\
40 \\
49\end{array}$ & $\begin{array}{l}\text { Gardener with soot } \\
\text { Turner } \\
\text { Worker with dyes } \\
\text { Chain maker } \\
\text { Arsenic and agricultural worker } \\
\text { Making heavy duty springs } \\
\text { Chain maker }\end{array}$ \\
\hline
\end{tabular}

Class i Textile

ii Automobile

iii Others

TABLE 7

Period from First ExPosure to TIME When MEdicAl AdVICE FIRST SOUGHT

\begin{tabular}{|c|c|c|c|c|c|}
\hline \multirow{2}{*}{ Years } & \multicolumn{4}{|c|}{ Group } & \multirow{2}{*}{ Total } \\
\hline & $A$ & $B$ & $C$ & $D$ & \\
\hline $10-19$ & - & - & 2 & - & 2 \\
\hline $20-39$ & 3 & 1 & 4 & 1 & 9 \\
\hline $40-59$ & 23 & 8 & 13 & 10 & 54 \\
\hline \multirow[t]{2}{*}{$60+$} & 14 & 2 & - & 3 & 19 \\
\hline & 40 & 11 & 19 & 14 & 84 \\
\hline
\end{tabular}

TABLE 8

Age at which first sought Medical Advice

\begin{tabular}{l|rrrrr|l}
\hline \multirow{2}{*}{ Age } & \multicolumn{5}{|c|}{ Group } & Total \\
\cline { 2 - 6 } & $A$ & $B$ & $C$ & $D$ & $E$ & \\
\hline $40-49$ & - & - & 3 & - & 1 & 4 \\
$50-59$ & 6 & 1 & 4 & 2 & 2 & 15 \\
$60-64$ & 6 & 5 & 3 & 3 & - & 17 \\
$65-69$ & 6 & 1 & 3 & 6 & - & 16 \\
$70-79$ & 13 & 4 & 6 & 1 & 2 & 26 \\
$80+$ & 9 & - & - & 2 & - & 11 \\
\hline Total & 40 & 11 & 19 & 14 & 5 & 89 \\
Mean age & 71 & 66 & $62 \cdot 5$ & 67 & 61 & $65 \cdot 5$ \\
& & & & & & \\
\hline
\end{tabular}


TABLE 9

Age at Death

\begin{tabular}{l|rrrrrr|r}
\hline \multirow{2}{*}{$\begin{array}{c}\text { Age } \\
\text { group }\end{array}$} & \multicolumn{5}{|c|}{ Group } & Total \\
\cline { 2 - 7 } & $A$ & $B$ & $C$ & $D$ & $E$ & \\
\hline 50 & - & - & 2 & - & - & 2 \\
$50-59$ & 2 & - & - & 2 & 1 & 5 \\
$60-69$ & 4 & 1 & 5 & 4 & - & 14 \\
$70-79$ & 5 & 3 & 4 & 1 & 2 & 15 \\
$80+$ & 10 & - & 1 & 3 & - & 14 \\
\hline Total & 21 & 4 & 12 & 10 & 3 & 50 \\
\hline
\end{tabular}

TABLE 10

Deaths Attributed to Scrotal Cancer and Deaths Attributed to Other Causes

\begin{tabular}{|c|c|c|c|c|c|c|c|}
\hline & \multicolumn{5}{|c|}{ Group } & \multirow{2}{*}{ Total } \\
\hline & & $A$ & $B$ & $C$ & $D$ & $E$ & \\
\hline \multicolumn{2}{|c|}{$\begin{array}{l}\text { Scrotal cancer the underlying } \\
\text { cause of death } . \\
\text { Scrotal cancer on death certi- } \\
\text { ficate, but not cause of death } \\
\text { Cause of death unrelated to } \\
\text { scrotal cancer } \quad \text {. . . }\end{array}$} & $\begin{array}{r}0 \\
14\end{array}$ & $\begin{array}{l}1 \\
1\end{array}$ & 5 & 5 & $\begin{array}{r}- \\
- \\
3\end{array}$ & $\begin{array}{r}19 \\
4 \\
27\end{array}$ \\
\hline $\begin{array}{l}\text { No. deceased } \\
\text { No. surviving }\end{array}$ & $\begin{array}{ll}\ldots & . \\
\ldots & . .\end{array}$ & $\begin{array}{l}21 \\
19\end{array}$ & $\begin{array}{l}4 \\
7\end{array}$ & $\begin{array}{r}12 \\
7\end{array}$ & $\begin{array}{r}10 \\
4\end{array}$ & $\begin{array}{l}3 \\
2\end{array}$ & $\begin{array}{l}50 \\
39\end{array}$ \\
\hline Total & .. & 40 & 11 & 19 & 14 & 5 & 89 \\
\hline
\end{tabular}

census data it has been possible to calculate an expected distribution for 89 subjects, and this is also shown in the table together with the ratio of observed to expected.

It will be seen for 1931 census data (Table 11) that the major excess is for occupational order XII with an observed figure of 46 and expected of 6.8 $(P<0.01)$. There is also an excess for order VII, but this is not statistically significant. For occupational order XXIII there is a considerable excess of expected over observed $(0.01<P<0.025)$ and similarly for the category not at work $(0.001<\mathrm{P}<$ 0.005).

For the 1951 census (Table 12), there was a marked excess in men reported as being in occupational order VII with an observed figure of 24 and expected of $3.75(P<0.001)$. There was also a marked excess for occupational order XXVI with an observed of 20 and expected of $9.26(P<0.001)$. However, the 20 were made up as follows: 8 in group A, 3 in group $\mathrm{B}, 4$ in group $\mathrm{C}$, and 5 in group $\mathrm{D}$, that is, just over half had been mule spinners at some time in their lives, although not at the time of the 1951 census.

\section{Discussion}

The results are reviewed here in an attempt to identify those occupations that expose workers to a risk of developing scrotal cancer and the proportion of cases that are of non-occupational origin.

Due to the small numbers in the study, great caution is required in interpreting the results. The comparison of the observed number of men with

TABLE 11

Observed Number of Men by Occupational Order grouped according to Occupation in 1931, with EXPECTED DISTRIBUTION

\begin{tabular}{|c|c|c|c|c|c|c|c|}
\hline \multirow{2}{*}{ No. } & \multirow{2}{*}{\multicolumn{2}{|c|}{$\begin{array}{l}\text { Occupational order } \\
\text { brief description }\end{array}$}} & \multicolumn{3}{|c|}{ No. of men } & \multirow{2}{*}{$\chi^{2}$} & \multirow{2}{*}{$\mathbf{P}^{1}$} \\
\hline & & & Observed & Expected & $O / E$ & & \\
\hline \multirow[t]{2}{*}{$\begin{array}{l}\text { III } \\
\text { IV } \\
\text { VI } \\
\text { XII } \\
\text { XIII } \\
\text { XV } \\
\text { XVIII } \\
\text { XXII } \\
\text { XXIII } \\
\text { XXIV } \\
\text { XXVIII } \\
\text { XXX } \\
\text { XXXI }\end{array}$} & 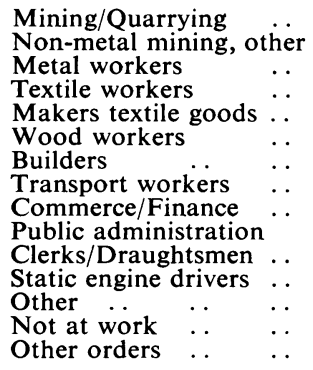 & $\begin{array}{l}\cdots \\
\cdots \\
\cdots \\
\cdots \\
\cdots \\
\cdots \\
\cdots \\
\cdots \\
\cdots \\
\cdots \\
\cdots \\
\cdots\end{array}$ & $\begin{array}{r}1 \\
1 \\
13 \\
46 \\
1 \\
1 \\
1 \\
7 \\
2 \\
1 \\
1 \\
2 \\
9 \\
3 \\
0\end{array}$ & $\begin{array}{r}3 \cdot 79 \\
0 \cdot 15 \\
9 \cdot 46 \\
6 \cdot 83 \\
1 \cdot 81 \\
3 \cdot 05 \\
3 \cdot 90 \\
11 \cdot 54 \\
10 \cdot 13 \\
0 \cdot 80 \\
5 \cdot 53 \\
1 \cdot 17 \\
12 \cdot 55 \\
14 \cdot 75 \\
3 \cdot 54\end{array}$ & $\begin{array}{l}0 \cdot 26 \\
6 \cdot 67 \\
1 \cdot 37 \\
6 \cdot 73 \\
0 \cdot 55 \\
0 \cdot 33 \\
0 \cdot 26 \\
0 \cdot 61 \\
0 \cdot 20 \\
1 \cdot 25 \\
0 \cdot 18 \\
1 \cdot 71 \\
0 \cdot 72 \\
0 \cdot 20 \\
0\end{array}$ & $\begin{array}{l}2 \cdot 1 \\
1 \cdot 3 \\
224 \\
1 \cdot 4 \\
2 \cdot 2 \\
1 \cdot 8 \\
6 \cdot 5 \\
3 \cdot 7 \\
1 \cdot 0 \\
9 \cdot 4 \\
3 \cdot 5\end{array}$ & $\begin{array}{cl} & \text { n.s. } \\
& \text { n.s. } \\
\text { n.s. } & \text { n. } \\
<0.001 & \text { n.s. } \\
\text { n.s. } & \text { n.s. } \\
& \text { n.s. } \\
0.01 & <. \mathbf{P}<0.02 \\
& \text { n.s. } \\
& \text { n.s. } \\
& \text { n.s. } \\
& \text { n.s. } \\
& <0.01 \\
& \text { n.s. }\end{array}$ \\
\hline & & & 89 & 89.00 & & & \\
\hline
\end{tabular}

${ }^{1}$ Where $\mathrm{E}>3$ probability calculated from chi square; for smaller values of E calculated as Poisson distribution. n.s. $=$ not significant $(\mathbf{P}<0.05)$. 
TABLE 12

Observed Number of Men by Occupational Order grouped according to OcCuPation in 1951, with EXPECTED DISTRIBUTION

\begin{tabular}{|c|c|c|c|c|c|c|}
\hline \multirow{2}{*}{ No. } & \multirow{2}{*}{$\begin{array}{l}\text { Occupational order } \\
\text { brief description }\end{array}$} & \multicolumn{3}{|c|}{ No. of men } & \multirow{2}{*}{$x^{2}$} & \multirow{2}{*}{$P^{1}$} \\
\hline & & Observed & Expected & $O / E$ & & \\
\hline $\begin{array}{l}\text { III } \\
\text { IV } \\
\text { VI } \\
\text { VII } \\
\text { XIV } \\
\text { XVII } \\
\text { XVIII } \\
\text { XIX } \\
\text { XXII } \\
\text { XXIV } \\
\text { XXV } \\
\text { XXVI } \\
\text { XXVII } \\
\text { XXVIII }\end{array}$ & 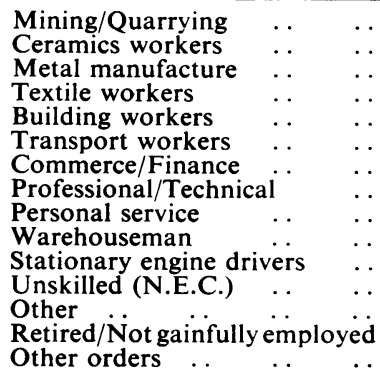 & $\begin{array}{r}1 \\
1 \\
19 \\
24 \\
1 \\
4 \\
1 \\
1 \\
3 \\
1 \\
3 \\
20 \\
1 \\
9 \\
0\end{array}$ & $\begin{array}{r}2 \cdot 07 \\
0.47 \\
14.64 \\
3 \cdot 75 \\
4.76 \\
9 \cdot 92 \\
8 \cdot 02 \\
4 \cdot 23 \\
2 \cdot 62 \\
2 \cdot 61 \\
1.59 \\
9 \cdot 26 \\
0.71 \\
12.13 \\
12 \cdot 22\end{array}$ & $\begin{array}{l}0.48 \\
2 \cdot 13 \\
1.30 \\
6 \cdot 40 \\
0.21 \\
0.40 \\
0.12 \\
0.24 \\
1.15 \\
0.38 \\
1.89 \\
2 \cdot 16 \\
1.41 \\
0.74 \\
0\end{array}$ & $\begin{array}{l}1 \cdot 3 \\
110 \\
3 \cdot 0 \\
3 \cdot 5 \\
6 \cdot 1 \\
2 \cdot 5\end{array}$ & $\begin{array}{c}\text { n.s. } \\
\text { n.s. } \\
\text { n.s. } \\
<0.001 \\
\text { n.s. } \\
\text { n.s. } \\
0.01<\text { P. } \\
\text { n.s. } \\
\text { n.s. } \\
\text { n.s. } \\
\text { n.s. } \\
\text { n.s. } \\
<0.02 \\
\text { n..0. } \\
\text { n.s. } \\
\text { n.s. } \\
<0.001\end{array}$ \\
\hline & Total & 89 & $89 \cdot 00$ & & & \\
\hline
\end{tabular}

${ }^{1}$ See footnote to Table 11

the expected number by occupational orders suggests that for very few of the occupational orders is there a high risk for scrotal cancer. This may be inaccurate because any one order comprises pooled data for many different occupations. The results based on one or two workers in particular occupations, therefore, require caution before assuming that the occupational environment gravely affects the risk of the disease.

The occurrence of two or more cases of scrotal cancer in any one occupational group might attract some attention, but the problem is made more difficult if one or more of these patients has also worked in an occupation in which there is a recognized hazard. In this survey, three patients had worked with dyes. If the patient in group D (Table 6), who had worked handling dyes under somewhat primitive conditions from 1907 to 1920 , had been the only one he might well have been put into group E. However, there were two other workers with dyes (in group B), one of whom had been a mule spinner for 12 years and a dye worker for 10 years and the other who had been a mule spinner for seven years tollowed by bobbin dyeing (often helping with mule spinning) over a period of about 10 years. He had spent a further 31 years assisting with the maintenance of machinery in a textile mill, an occupation which is associated with a risk of scrotal cancer. Henry (1946) suspected a hazard of cutaneous cancer associated with the process of the purification of anthracene oil in the dyestuffs industry.

Another example of this situation is leather workers. The patient noted in Table 4, class c, was a mule spinner for three years, then a leather worker for 21 years; afterwards he was a sales representative for a leather firm but he carried no hides. The only other leather worker found in this survey was a clerk in a tannery works for more than 10 years. He has been placed in group $\mathrm{E}$ as his work was entirely clerical and did not take him into the factory.

In Table 5, there is one patient in class $c$ 'other exposure'. He had spent seven years on road making in which there may be a hazard from the tar or bitumen used for surfacing, although, in this case, no definite exposure of this sort could be established. He had spent 43 years as a barbed wire machine operator with exposure to mineral oil. Henry (1946) found one man who had been a barbed wire machinist, although that man had, in addition, worked as a mule spinner for three years (an unusually short exposure from which to have developed scrotal cancer).

The most notable finding in Table 5 is the appearance of 10 machine operators. Several reports (Cruickshank and Squire, 1950; Cruickshank and Gourevitch, 1952; Fife, 1962) have drawn attention to the hazard of skin cancer from this occupation in the Birmingham area. During the course of our study, two further cases were found in the same firm as that of one of our patients, but they were not registered during the period 1962-8. Three of the men who first sought medical advice in their forties (Table 8) were in group C. Two had worked as autosetters and one as a capstan lathe operator.

In Table 6 appear those occupations which are not generally associated with a scrotal cancer risk. The four textile workers were all exposed to mineral oil from the machines. Henry (1946) found that the 
incidence among all card room workers was about 28 per million compared with four for the general population. (In contrast, his figures for cotton mule spinners and tar distillery workers were 420 and 315 per million). The three cases coming from the automobile industry (class ii) are of particular interest for the numbers exposed have grown enormously in the past 30 or 40 years, although conditions have changed as well. One had been a wool ring spinner for part of his life but that occupation has been free from hazard. All the men in class iii had clearly been exposed to oil or soot apart from the worker with dyes already mentioned and the man who had worked in the manufacture of arsenical sheep dip. Henry (1946) found two cases from this latter occupation, one of whom had been exposed to tar at the same time. In a footnote, he refers to a third man who had been an arsenical sheep dip worker for five years and subsequently became a roadman in contact with tar for 33 years. The appearance of two chain makers in this table is interesting because Fife (1962) found one 'chain assembler' among 79 cases of skin cancer due to mineral oil in industries other than the cotton trade.

Cancer of the scrotum is a disease of the elderly; 37 out of $89(41 \%)$ were 70 or over when they first sought medical advice (Table 8 ) and $58 \%$ of the deaths occurred in men of 70 or over (Table 9). It would be expected, therefore, that some of the patients registered with this condition died from other causes. Scrotal cancer was coded as the underlying cause of death in only 19 of the 50 deaths (Table 10).

In groups $\mathrm{A}$ and $\mathrm{B}$, the period from first exposure to first seeking medical advice tended to be somewhat longer than in groups $C$ and $D$ (Table 7) $\left(\chi^{2}=\right.$ 7.38 ; d.f. $=2 ; 0.005<\mathrm{P}<0.01)$. Also the men in groups $A$ and $B$ sought medical advice at an older age (Table 8) $\left(\chi^{2}=5.20\right.$; d.f. $=2 ; 0.01<\mathrm{P}<$ $0.025)$. They represent 'survivor' populations. The Mule Spinning (Health) Special Regulations (1953) came into operation to combat this hazard in 1954. Cotton mule spinning has rapidly declined, particularly since about 1930 (Robson, 1957; Fig. 1). Although our figures do not suggest any decrease in the number of cases among mule spinners, Fig. 2, which compares the age distribution of our cases and those in a Home Office Report of 1926 when the epidemic of scrotal cancer was at its height, shows that the cases appearing now tend to be older.

Three persons, one each in groups $\mathrm{A}, \mathrm{C}$, and $\mathrm{D}$ (Tables 3, 5, and 6), had less than 10 years' exposure. One man had been a mule spinner for nine years, followed by 21 years as an orderly in an officers' mess in the Army, after which he returned to a mill, but not as a mule spinner. The shor test exposure as a mule spinner in Henry's (1946) much larger series was one year. The second, born in 1895, had worked

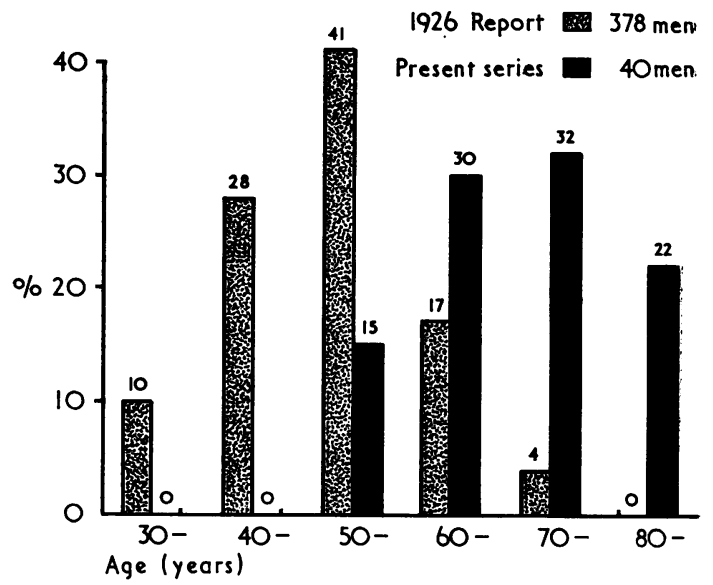

FIG. 2. Comparison of age distribution of mule spinners with scrotal cancer (when disease first recognized) between present series and 1926 Report.

for the Highways Department of the local authority using pitch, from 1918 to 1921 and again from 1936 to 1939 - a total exposure of six years. The third man, born in 1901, had started work at the age of 14 as a gardener, handling and spreading large quantities of soot, and continued in this occupation for six years, after which he had trained as a barman and steward and forlowed that job for the remainder of his life. Pott (1808) reported a case of cancer on the wrist of a gardener who had been scattering soot every spring to kill slugs.

Seventy-three of our 84 men $(86 \%)$ in groups $A$, B, C, and D sought medical advice 40 or more years after their first exposure. In the same groups, 51 out of $84(60 \%)$ did not seek medical advice until they were 65 years or older (Table 8), that is, when the possibility of early detection by routine examination in industry or some such form of supervision would have passed.

Seventy-three men were followed up for at least five years after they first sought medical advice and $30(41 \%)$ were still living. Thirty-six men, who were 70 or more years old when they first sought medical advice, were followed up for at least five years and only $12(33 \%)$ were still alive. Twenty-four men, who first sought medical advice between the ages of 40 and 64 , were followed up for five or more years and $13(54 \%)$ were still alive. These figures reflect the risk of death from other causes rising with increasing age. They do not suggest that the progress of the disease is more rapid in the younger age groups.

Of the 50 men who died, seven were under 60 at the time of death (Table 9); two had been mule spinners; two had worked at machine tools, one 
as a capstan lathe operator for 20 years and one as an auto machine operator for 31 years. Two in group D may have been heavily exposed to oil. One of these had worked as a car assembler from 1922 to 1932 for a firm long since out of business so that no further information could be obtained. After that he had worked for nine years for a timber firm but had not been exposed to any preservatives. He then worked for four years on a brewery delivery dray, and finally for 16 years as an instrument attendant in an orchestra. He used no resins or oil but was concerned to a small extent with the maintenance of the instruments. The other man from group $D$ had worked for $\mathbf{4 2}$ years making heavy-duty springs and his job was described as very oily. We were told that he was frequently wet from oil from the waist to the knees. Finally, there was one man in group E who had been a haulage driver for 26 years. As he was dead, his history was obtained from his sister and it cannot be certain that he had not assisted in the mechanical maintenance of his vehicle.

It is worth remarking on the absence of any gas workers in this survey. Henry (1946) found over 60 out of 1631 fatal cases and Cruickshank and Squire (1950) found three gas workers in a survey of 34 cases of scrotal cancer in the Birmingham area over the years 1939 to 1948 . There may be many reasons for the absence of any cases in our survey, but it may be noted that in 1952 an occupational medical service was set up in the gas industry in this area and has particularly concentrated on the examination of the skin of exposed workers. Some cases occurring in retired gas workers, no longer under close medical surveillance, might have been expected. It is unlikely that the effects of recent technological changes in the gas industry would be apparent in the present survey because of the long latent period of the condition.

\section{Conclusions}

Geographical factors influence the distribution of industry and, therefore, the incidence of scrotal cancer. The anticipated high number of mule spinners was found in this area. On the other hand, the discovery of a patient whose chief occupation had been a ship's engineer suggests that it might be useful to investigate that occupation in areas where such cases are more likely to be seen.

Four other occupational groups call for comment. Automatic lathe operating produced a number of cases and it is disturbing that these tended to affect the young who died young. While measures may have been taken within industry to combat this, a prospective study of that industry would indicate the present incidence and, if the study is continued, it will monitor the effectiveness or otherwise of preventive measures. Similar considerations apply to road making. This occupation is largely under the control of local authorities who may undertake the work themselves or contract it out. It might be possible for them to initiate a prospective study to monitor the effectiveness of their preventive measures. Some 30 years ago, Henry suspected a hazard in workers with dyes. Our survey has done nothing to allay that suspicion. Two chain makers have been noted in this survey and it would be worthwhile to investigate the prevalence in this occupation more closely.

Finally, it has been shown that most men sought medical advice 40 or more years after the first exposure, when many might have left the hazardous occupation. Furthermore, $42 \%$ of the scrotal cancers (other than in mule spinners) developed after the men had passed the age of retirement and therefore too late for any routine medical examination, statutory or voluntary, at the workplace to be of any value. For these reasons, it would seem that some other pattern of medical surveillance of those at high risk should be considered.

We are grateful to the Manchester Regional Hospital Board for financial support for this investigation and to the consultants and general practitioners looking after the patients for their help and co-operation.

\section{References}

Cruickshank, C. N. D., and Gourevitch, A. (1952). Skin cancer of the hand and forearm. Brit. J. industr. Med., 9, 74-79.

-, and Squire, J. R. (1950). Skin cancer in the engineering industry from the use of mineral oil. Brit. J. industr. Med., 7, 1-11.

Fife, J. G. (1962). Carcinoma of the skin in machine tool setters. Brit. J. industr. Med., 19, 123-125.

General Register Office (1934). Census of England and Wales 1931-Occupation Tables, H.M.S.O., London.

- (1956). Census of England and Wales 1951-Occupation Tables. H.M.S.O., London.

Henry, S. A. (1946). Cancer of the Scrotum in relation to Occupation. Oxford University Press, London.

Home Office (1926). Report of the Departmental Committee Appointed to Consider Evidence as to the Occurrence of Epitheliomatous Ulceration among Mule Spinners. H.M.S.O., London.

Kipling, M. D. (1968). Annual Report of H.M. Chief Inspector of Factories for 1967, p. 105. H.M.S.O., London.

Medical Research Council (1968). The carcinogenic action of mineral oils: a chemical and biological study. Spec. Rep. Ser. No. 306 (Lond.).

Mule Spinning (Health) Special Regulations (1953). S.I. No. 1545. H.M.S.O., London.

Pott, Percivall (1808). The Chirurgical Works of Percivall Pott, a new ed., to which are added... Occasional Notes and Observations by Sir James Earle. vol. 3. London.

Robson, R. (1957). The Cotton Industry in Britain, p. 339. Macmillan, London.

Stokes $v$. Guest, Keen and Nettlefold Ltd. (1968). 1 Weekly Law Reports 1776.

Received for publication June 25, 1971. 